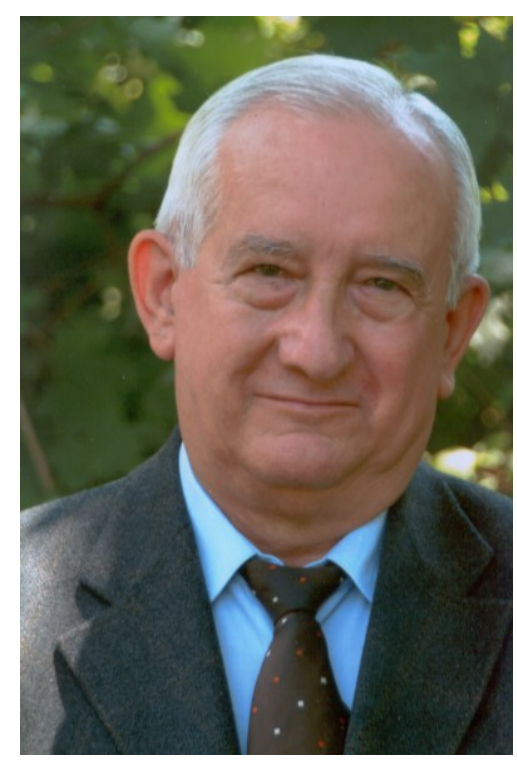

\title{
Várallyay György 80 éves
}

A magyar talajtan nemzetközileg is elismert kiemelkedő egyénisége, Várallyay György, 2015. július 17-én ünnepli nyolcvanadik születésnapját.

A kerek évfordulók alkalmasak részletesebb áttekintésekre, lehetőséget biztosítanak arra, hogy rohanó életünkbe egy kis pihenőt iktassunk és a barátok, kollégák, a talajtan és az agrokémia szakterületein dolgozó munkatársak kifejezhessék tiszteletüket, megbecsülésüket és jókívánságaikat. Várallyay György eredményekben gazdag és töretlen ívú pályájának sikere mögött sok-sok tanulással, tapasztalatszerzéssel és szorgalmas munkával töltött év áll, amely kiegészül a nélkülözhetetlen tehetséggel, a céltudatos kitartással és áldozatvállalással. A nagyívű életpályák jellemzöje, hogy nem lehet tárgyszerủ és szigorú időrendi sorrendet követni, a szemelvények bemutatása, a tisztelgő válogatás is majdnem meghaladja a kereteket.

Várallyay György életpályájának indításában jelentős szerepet játszott a tudományos elhívatottságot kiváltó családi háttér. Az agrármérnöki diplomát a Gödöllői Agrártudományi Egyetemen 1957-ben szerezte kitüntetéssel. 1957-töl 1960-ig az Országos Mezőgazdasági Minőségvizsgáló Intézet Mosonmagyaróvári Talajtani Osztályán dolgozott, ahol talajtérképezés és talajjavítási szaktanácsadás volt a feladata. A Kisalföldön végzett talajfelvételezés alapozta meg és mélyítette el talajtérképezési és mezőgazdasági szaktanácsadási ismereteit. 
Talajtani tudásának tudományos szintủ művelési lehetőségét adta számára Szabolcs István meghívása a MTA Talajtani és Agrokémiai Kutatóintézetbe 1960-ban. A Szikkutatási és Hasznosítási Osztályra kerülve Szabolcs István szakmai vezetésével kezdetben a szikes talajok térképezésével, öntözésének hatásaival, sóforgalmával, vízgazdálkodási tulajdonságainak vizsgálatával foglalkozott. Egyetemi doktori értekezését 1964-ben az Iván környéki szikes talajokról és azok képződéséről írta, majd négy évvel később a Duna-völgy talajainak sófelhalmozódási folyamatairól, sóforgalmáról és sómérlegeiről készítette és védte meg kandidátusi értekezését. Az Intézetünkben töltött első nyolc év tudományos eredményeinek mérlege önmagában is imponáló, magában hordozza a későbbi sikerek alapját és követendő példaként szolgálhat ma is a fiatal kollégák számára. Ez időszak alatt kapcsolódott be a Nemzetközi Talajtani Társaság Szikes Albizottságának munkájába és szakértőként dolgozott Jemenben.

A sikeresen induló pálya 1969-ben egy hollandiai ösztöndíjas tanulmányút alkalmával módosul, szélesedik, témát vált. Átveszi, majd bevezeti Magyarországon a korszerü talajfizikai és vízgazdálkodási vizsgálati módszereket. Elévülhetetlen érdeme, hogy a MÉM Talajfizikai Laboratóriumok számára összeállított, a talaj fizikai- és vízgazdálkodási tulajdonságainak vizsgálatára 1978-ban kiadott MÉM szabványban már ezeket az elveket és módszereket fogalmazta meg. Ezáltal az MTA Talajtani és Agrokémiai Kutatóintézet példájára az 1970-es évek elején kialakított korszerü vizsgálati módszertan kerülhetett bevezetésre a mezőgazdasági rutinvizsgálati módszerek sorába.

1976-ban megbízást kapott az Intézet Talajtani Osztályának vezetésére. Az osztályvezetéshez nagy lelkesedéssel és a talajtan iránti elkötelezettséggel látott hozzá. A négyéves osztályvezetői időszaka alatt „Az ország agroökológiai potenciáljának felmérése" - Láng István kezdeményezte - akadémiai program talajtani adathátterének összeállítása volt egyik legjelentősebb feladata. A munka során hét (később kilenc) talajjellemzőt tartalmazó 1:100 000 léptékü talajtérkép megszerkesztésére került sor. További tevékenységéhez tartozott az új kategória-rendszer kidolgozása a talajok vízgazdálkodásának jellemzésére; valamint a Kiskunsági Nemzeti Park 1:25 000 léptékü termőhely-térképezési munkálatainak megkezdése.

Az 1981-től vállalt intézetigazgatói feladatok a szakmai fejlődésben a súlypontot áttették a tudományos közéletben végzett egyre szerteágazóbb feladatokat jelentő szerepvállalásokra, valamint az agrár- és a természettudományi egyetemek graduális és posztgraduális képzésében történő intenzív részvételre. Az intézetinél szélesebb fórumra kilépett Várallyay György a hazai és a nemzetközi üléseken szakértelmével, felkészültségével megbecsülést szerzett a magyar talajtani szakmának. Szakismerete, élvezetes stílusú előadásai pedig népszerüsítették a talajtanhoz kapcsolódó tárgyakat az egyetemi hallgatók körében. „A talaj vízgazdálkodása” címü értekezésével, amelyben a talajfizika és vízgazdálkodás témakörében végzett tevékenységének eredményeit foglalta össze, a mezőgazdaság tudomány doktora fokozatot szerzett 1988-ban. 
Tudományos minősítése, valamint gazdag publikációs tevékenysége (több mint 600 magyar és idegennyelvü publikáció), tudományos és népszerüsitő előadásainak sora (több mint 1250 ), a tudományos közéletben betöltött sokrétủ és aktív szerepvállalása (MTA Talajtani Bizottságának titkára 1970-től, majd elnöke 1993-tól, MTA Környezettudományi Bizottság, MTA Környezet és Egészség Bizottság, MTA Hidrológiai Tudományos Bizottság, MTA Aszály Bizottság, a DE ATC, NyME és a SzIE Habilitációs Bizottságának és Doktori Tanácsának tagja), hazai és nemzetközi folyóiratok szerkesztőbizottsági tagsága (Acta Agronomica, Hidrológiai Közlöny, Archives of Agronomy and Soil Science, Geoderma, International Agrophysics, Land Degradation and Rehabilitation és Soil Technology) bizonyítják munkásságának eredményességét, széles körü elismertségét.

Az „Agrokémia és Talajtan” című tudományos folyóírat föszerkesztője. A szakmai-tudományos közvélemény megbecsülésének eredményeként 1993-ban a Magyar Tudományos Akadémia levelező tagjává, majd 1998-ban rendes tagjává választották. Ez a tény nemcsak Várallyay György szakmai sikereinek elismerését, hanem egyben a talajtani tudomány hazai megbecsülését is jelentette. Mint akadémiai tag fontos tudományos és oktatási döntéshozó testületekben fejthette és fejtheti ki a talajtani tudomány iránt érzett köztudott elkötelezettségét (MTA Élettudományi Kuratóriuma, az Országos Akkreditációs Bizottság, MTA Doktori Tanács, Országos Környezetvédelmi Tanács stb.). Az eddig felsoroltak mellett számos további hazai és nemzetközi bizottság tagja és tisztségviselője volt, pl. a MAE Talajtani Bizottság elnöke, a Nemzetközi Talajtani Társaság (ISSS, majd IUSS) tagja, az ISSS VI. Talajtechnológia Bizottságának volt elnöke, az ISSS Szervezeti Szabályzat és Nemzetközi Programok és a Szlovák Mezőgazdasági Akadémia külső tagja.

Állami kitüntetések is jelzik az elismerést: a „Vízgazdálkodás Kiváló Dolgozója" kitüntetésben 1976-ban, a Munka Érdemrend ezüst fokozata kitüntetésben 1985ben, a Magyar Köztársasági Érdemrend Középkeresztje kitüntetésben 1997-ben részesült. 2004-ben a talajtan területén kifejtett már akkor közel 50 éves sikeres munkássága, nemzetközileg is széles körüen elismert tudományos eredményei, sokoldalú iskolateremtő oktatási és tudományos továbbképzési tevékenysége elismeréseként Széchenyi-dijat vehetett át.

Amikor születésnapja alkalmából Várallyay Györgynek az eddigi eredményeihez öszintén gratulálunk és a további sikerekhez jó egészséget kívánunk, reméljük, hogy még hosszú időszakon át élvezhetjük aktivítását, hasznosíthatjuk bölcs tanácsait. A kiszámítható, következetes tenni vágyás hajtotta egész szakmai tevékenységében, $\mathrm{s}$ érdekes - számunkra is fontos - esemény keretezi Professzor Úr ezévi kerek évfordulóját, az ENSZ 2015-öt a „TALAJ ÉVÉ-nek” szenteli. Természetesen Várallyay György mind a hazai, mind a nemzetközi „TALAJ ÉVE” rendezvényeken tevékenyen részt vesz. Igaz ez a 2015 március 9-i megnyítóra, a május 27-én tartandó MTA ATK Talajtani és Agrokémiai Intézet jubileumi ülésére és a december 4-ére tervezett záróünnepségre is. 
